University of Nebraska - Lincoln

DigitalCommons@University of Nebraska - Lincoln

Faculty Publications: Department of

Entomology

Entomology, Department of

2011

\title{
Dose-Response Relationships of Clothianidin, Imidacloprid, and Thiamethoxam to Blissus occiduus (Hemiptera: Blissidae)
}

\author{
M. D. Stamm \\ University of Nebraska-Lincoln, mstamm3@unl.edu \\ Frederick P. Baxendale \\ University of Nebraska-Lincoln, fbaxendale1@unl.edu \\ Tiffany Heng-Moss \\ University of Nebraska-Lincoln, thengmoss2@unl.edu \\ Blair D. Siegfried \\ University of Nebraska-Lincoln, bsiegfried1@ufl.edu \\ Erin E. Blankenship \\ University of Nebraska-Lincoln, erin.blankenship@unl.edu
}

See next page for additional authors

Follow this and additional works at: https://digitalcommons.unl.edu/entomologyfacpub

Part of the Entomology Commons

Stamm, M. D.; Baxendale, Frederick P.; Heng-Moss, Tiffany; Siegfried, Blair D.; Blankenship, Erin E.; and Gaussoin, Roch E., "Dose-Response Relationships of Clothianidin, Imidacloprid, and Thiamethoxam to Blissus occiduus (Hemiptera: Blissidae)" (2011). Faculty Publications: Department of Entomology. 269. https://digitalcommons.unl.edu/entomologyfacpub/269

This Article is brought to you for free and open access by the Entomology, Department of at DigitalCommons@University of Nebraska - Lincoln. It has been accepted for inclusion in Faculty Publications: Department of Entomology by an authorized administrator of DigitalCommons@University of Nebraska - Lincoln. 


\section{Authors}

M. D. Stamm, Frederick P. Baxendale, Tiffany Heng-Moss, Blair D. Siegfried, Erin E. Blankenship, and Roch E. Gaussoin 


\title{
Dose-Response Relationships of Clothianidin, Imidacloprid, and Thiamethoxam to Blissus occiduus (Hemiptera: Blissidae)
}

\author{
M. D. STAMM ${ }^{1,2}$ F. P. BAXENDALE ${ }^{1}$ T. M. HENG-MOSS ${ }^{1}$ B. D. SIEGFRIED, ${ }^{1}$ \\ E. E. BLANKENSHIP, ${ }^{3}$ AND R. E. GAUSSOIN ${ }^{4}$
}

\begin{abstract}
J. Econ. Entomol. 104(1): 205-210 (2011); DOI: 10.1603/EC10268
ABSTRACT The western chinch bug, Blissus occiduus Barber (Hemiptera: Blissidae), has emerged as a serious pest of buffalograss, Buchloë dactyloides (Nuttall) Engelmann. In general, neonicotinoid insecticides effectively control a variety of turfgrass insects, particularly phloem-feeding pests. However, because of well documented inconsistencies in control, these compounds are generally not recommended for chinch bugs. This study was designed to document the contact and systemic toxicity of three neonicotinoid insecticides (clothianidin, imidacloprid, and thiamethoxam) to B. occiduus. In contact bioassays, thiamethoxam was $\approx 20$-fold less toxic than clothianidin or imidacloprid to $B$. occiduus nymphs and three-fold more toxic to adults. In adult systemic bioassays, thiamethoxam was up to five-fold more toxic than clothianidin or imidacloprid. Interestingly, thiamethoxam was significantly more toxic to adults than to nymphs in both contact and systemic bioassays. This was not observed with clothianidin or imidacloprid. Bifenthrin, used for comparative purposes, exhibited 1,844-fold and 122-fold increase in toxicity to nymphs and adults, respectively. These results provide the first documentation of the relative toxicity of these neonicotinoid insecticides to B. occiduus.
\end{abstract}

KEY WORDS chinch bug, Blissus occiduus, buffalograss, neonicotinoids, LC $_{50}$

Buffalograss, Buchloë dactyloides (Nuttall) Engelmann, a perennial warm-season grass, continues to gain in popularity as a turfgrass due to its low maintenance requirements and exceptional heat and drought tolerance. Compared with traditional turfgrass species, it is relatively free of diseases and arthropod pests when grown for turf, sod, or seed (Baxendale et al. 1999). Over the past two decades, however, the western chinch bug, Blissus occiduus Barber (Hemiptera: Blissidae), has emerged as a serious buffalograss pest. This chinch bug is widely distributed from California, Colorado, Kansas, Montana, Nebraska, and New Mexico in the United States, and Alberta, British Columbia, Manitoba, and Saskatchewan in Canada (Bird and Mitchener 1950, Slater 1964, Baxendale et al. 1999).

In Nebraska, B. occiduus has two generations each year and overwinters as an adult within the turfgrass stand. The first generation completes development by mid-June and is present until mid-August (Baxendale et al. 1999). Second generation adults appear in late August and remain active until fall temperatures cool. Overwintering adults are primarily brachypterous (Baxendale et al. 1999).

\footnotetext{
${ }^{1}$ Department of Entomology, University of Nebraska-Lincoln, 202 Entomology Hall, Lincoln, NE 68583.

2 Corresponding author, e-mail: mstamm3@unl.edu.

${ }^{3}$ Department of Statistics, University of Nebraska-Lincoln, 343B Hardin Hall North, Lincoln, NE 68583.

${ }^{4}$ Department of Agronomy and Horticulture, University of Nebraska-Lincoln, 362H PLSH, Lincoln, NE 68583.
}

Chinch bugs injure grasses by withdrawing sap from stolons and plant tissues in the crown area (Baxendale et al. 1999). It has been hypothesized that chinch bugs inject salivary toxins while feeding (Painter 1928, Potter 1998), which may result in plant damage by inhibiting water and nutrient translocation (Heng-Moss et al. 2005). Early symptoms of chinch bug infestations include reddish purple discoloration of the leaves. As feeding progresses, damage results in patchy turfgrass stands, which turn yellow and dry to a straw-brown color. At higher infestation levels, chinch bug feeding can cause severe thinning or death of the turfgrass stand (Baxendale et al. 1999).

Insecticides, including the neonicotinoids, provide an important management option for controlling a wide range of piercing-sucking insect pests, including the turfgrass-inhabiting chinch bugs Blissus leucopterus leucopterus Say, Blissus leucopterus hirtus Montandon, Blissus insularis Barber, and Blissus occiduus Barber. Neonicotinoid insecticides feature broadspectrum activity, low application rates, excellent systemic uptake and translocation in plants, a novel mode of action, and reduced environmental hazards (Maienfisch et al. 2001a). When applied to the soil, these insecticides are taken up by the roots and distributed throughout the plant to give long-lasting control against many sucking pests (Elbert et al. 2008). Neonicotinoids are agonists of the postsynaptic nicotine acetylcholine receptors (nAChRs) of the insect central nervous system (Nauen et al. 1998). The low toxicological risk of neonicotinoid insecticides to non- 
target species, particularly mammalian species, has been attributed to their selective activity on insect nAChRs (Soloway et al. 1978, Badio and Daly 1994).

Limited information is available on the toxicity of the neonicotinoid insecticides to chinch bugs. Although neonicotinoids are most commonly associated with their systemic properties, some studies suggest substantial contact activity as well (Nauen and Elbert 1994). This study was designed to document the contact and systemic toxicity of three neonicotinoid insecticides-clothianidin, imidacloprid, and thiamethoxam-to B. occiduus.

\section{Materials and Methods}

Buffalograss and Chinch Bugs. Plugs of 'Prestige' buffalograss (10.6 $\mathrm{cm}$ in diameter by $8 \mathrm{~cm}$ in depth) were removed from field plots at the John Seaton Anderson Turfgrass and Ornamental Research Facility, University of Nebraska Agricultural Research and Development Center (Saunders Co., NE) (Eickhoff et al. 2008). Plugs were vegetatively propagated in "Custom container" plastic nursery pots $(17 \mathrm{~cm}$ in diameter by $13.3 \mathrm{~cm}$ in depth) (Hummert International, Earth City, MO) containing a 2:1:3:3 potting mixture ratio of sand-soil-peat-perlite. The buffalograss plants were maintained in a greenhouse under 400-W high-intensity discharge lamps with a photoperiod of 16:8 (L:D) $\mathrm{h}$ and irrigated as needed. These plants provided vegetative material for systemic insecticide bioassays.

B. occiduus were collected from buffalograss stands at the University of Nebraska (Lancaster Co., NE) with no history of insecticide use during the past $5 \mathrm{yr}$ by vacuuming the soil surface with an ECHO Shred 'N' Vac (model 2400, ECHO Inc., Lake Zurich, IL) (Eickhoff et al. 2008). Chinch bugs were sifted from samples through a 2-mm mesh screen and collected with an aspirator (Heng-Moss et al. 2002, Eickhoff et al. 2008).

Separate bioassays were conducted to assess the systemic and contact toxicity of selected insecticides on chinch bug adult and nymphal mortality. Ten unsexed chinch bug adults and 10 nymphs (third and fourth instars) were placed in either insecticidetreated scintillation vials (contact bioassays) or exposed to insecticide treated buffalograss plants (systemic bioassays). Insecticides included technical grade bifenthrin $(99.0 \%$ [AI]), clothianidin $(99.4 \%$ [AI]), imidacloprid (99.5\% [AI]), and thiamethoxam (99.5\% [AI]) purchased from Chem Service Inc. (West Chester, PA). Technical grade insecticides were diluted in reagent grade acetone.

Preliminary systemic and contact bioassays using five 10 -fold dilutions $(0.01,0.1,1.0,10.0$, and 100.0 $\mu \mathrm{g} / \mathrm{ml})$ identified approximate lethal concentrations $\left(\mathrm{LC}_{50}\right)$ for both nymphs and adults. Concurrent studies also assessed the same five 10-fold dilutions against first and second generation chinch bug nymphs and adults to identify potential insecticide response differences between generations. Finally, a study assessing the optimal interval for assessing B. occiduus mortality revealed that chinch bug mortality was first observed $4 \mathrm{~h}$ after exposure in the systemic and contact bioassays. Therefore, mortality was evaluated beginning $4 \mathrm{~h}$ after chinch bug introduction for both bioassays.

Mortality assessments were carried out by gently probing individual insects and assigning a visual rating of alive, moribund, or dead. Living individuals were defined as those able to move freely and responded when probed. Individuals were classified as moribund if uncontrolled twitching and other movements were observed or if chinch bugs displayed difficulty in moving. Chinch bugs were considered dead if they would not respond to probing. Preliminary studies have demonstrated that moribund chinch bugs were not able to recover from insecticide exposure. Therefore, these individuals were grouped with those recorded as dead for statistical analyses.

Systemic Bioassays. For systemic bioassays, experimental enclosures were assembled using 15-ml test tubes (Fisher Scientific, Pittsburg, PA) and 30-ml portion cups (Covalence Plastics, Minneapolis, MN) glued together using an ethyl acetate solvent. The roots of individual buffalograss plants were cut to $7 \mathrm{~cm}$, placed in the test tubes containing serial insecticide dilutions, and sealed with molten $\left(63 \pm 2^{\circ} \mathrm{C}\right)$ paraffin wax (Gulf Wax, Royal Oaks Sales, Inc., Roswell, GA) to prevent insecticidal contact with the chinch bugs (Eickhoff et al. 2008). Roots and leaf blades measured 7 and $4 \mathrm{~cm}$ in length, respectively.

Enclosures were held overnight $(\approx 14 \mathrm{~h})$ at $28 \pm 2{ }^{\circ} \mathrm{C}$ with a photoperiod of 16:8 (L:D) h to allow for insecticide uptake. Chinch bugs used in systemic bioassays were held for $\approx 17 \mathrm{~h}$ under ambient conditions ( $22 \pm 3^{\circ} \mathrm{C}$ and a photoperiod of 24:0 [L:D] h) without food to ensure active feeding during bioassays.

Insecticide stock solutions were serially diluted in double distilled water. The serial dilutions were projected to give $0-100 \%$ chinch bug mortality. Fifteen milliliters of each serial dilution was pipetted into the test tubes. Double distilled water was used in the control with five concentrations per bioassay. Plant roots were submerged in clothianidin, imidacloprid, or thiamethoxam dilutions for systemic uptake into stems and leaves. Five concentrations were selected based on the preliminary studies described above.

An initial bioassay was conducted in 2008 on first generation B. occiduus adults, and repeated in 2009 on first generation nymphs (third and fourth instar). The experiment was a completely randomized design (CRD) with three to six replications per treatment. The concentrations used for nymphs were $0.03,0.3$, 3.0,30.0, and $300.0 \mu \mathrm{g} / \mathrm{ml}$ for clothianidin; $0.01,0.1,1.0$, 10.0, and $100.0 \mu \mathrm{g} / \mathrm{ml}$ for imidacloprid; and 0.1, 0.5, 2.2, 8.8 , and $35.0 \mu \mathrm{g} / \mathrm{ml}$ for thiamethoxam. For adults, all insecticide concentrations were $0.01,0.1,1.0,10.0$, and $100.0 \mu \mathrm{g} / \mathrm{ml}$ with six replications per treatment.

Contact Bioassays. For contact assays, 20-ml glass scintillation vials (Wheaton Industries Inc., Millville, $\mathrm{NJ}$ ) were treated with $500 \mu \mathrm{l}$ of diluted insecticide or acetone and then rolled for $\approx 0.5 \mathrm{~h}$ on a commercial hotdog roller at room temperature $\left(22 \pm 3^{\circ} \mathrm{C}\right)$ until dry (Scharf et al. 1999). Vials were then maintained at 
Table 1. Nymphal B. occiduus susceptibility from exposure to clothianidin, imidacloprid, and thiamethoxam systemic bioassays

\begin{tabular}{lcccc}
\hline \hline Insecticide & $n$ & Slope $\pm \mathrm{SE}$ & $\mathrm{LC}_{50} \mu \mathrm{g} / \mathrm{ml}(95 \% \mathrm{CL})^{a}$ & $\mathrm{LC}_{90} \mu \mathrm{g} / \mathrm{ml}(95 \% \mathrm{CL})$ \\
\hline Clothianidin & 360 & $0.06 \pm 4.17$ & $16.58(8.22-24.94)$ & $55.80(28.30-83.30)$ \\
Imidacloprid & 360 & $0.05 \pm 5.51$ & $18.91(7.85-29.97)$ & $61.95(28.41-95.49)$ \\
Thiamethoxam & 360 & $0.05 \pm 5.12$ & $24.58(14.32-34.85)$ & $67.87(37.60-98.14)$ \\
\hline
\end{tabular}

${ }^{a}$ Concentration that produces $50 \%$ mortality in the population relative to the untreated controls. Calculated using a generalized linear model.

$28 \pm 2^{\circ} \mathrm{C}$ under 24 -h lighting until evaluation at $4 \mathrm{~h}$ after chinch bug introduction. Because chinch bug feeding was not required for contact bioassays, chinch bugs were held for only $2 \mathrm{~h}$ before placement in vials.

Serial dilutions of clothianidin, imidacloprid, thiamethoxam, or bifenthrin in acetone were pipetted into scintillation vials. Bifenthrin, a pyrethroid known for its toxicity as contact insecticides (Elliot et al. 1978), was used for comparison purposes. The acetone was assumed to have no effect on chinch bug mortality (Magalhaes et al. 2008). As with the systemic bioassays, concentrations were determined through preliminary studies.

Contact bioassays were conducted on first generation adults in 2008 and then repeated in 2009 on both first and second generation nymphs (third and fourth instar). The experimental design was a CRD with the number of replications ranging from three to six depending on the level of variability within a treatment. Final concentrations used for nymphs were $0.03,0.1$, $0.5,2.1$, and $8.4 \mu \mathrm{g} / \mathrm{ml}$ for clothianidin and imidacloprid; $0.002,0.005,0.010,0.012$, and $0.040 \mu \mathrm{g} / \mathrm{ml}$ for bifenthrin; and $0.2,0.6,0.9,2.5,2.6,7.6,9.5,10.0,17.1$, $23.0,30.9,40.0,55.6,70.0$, and $100.0 \mu \mathrm{g} / \mathrm{ml}$ for thiamethoxam. For adults, all insecticides concentrations were $0.01,0.1,1.0,10.0$, and $100.0 \mu \mathrm{g} / \mathrm{ml}$ with six replications per treatment.

Statistical Analysis. Mortality data were analyzed using probit analysis (Finney 1971) implemented in PROC NLMIXED (SAS Institute 2006). Four-hour lethal concentrations were determined for both chinch bug bioassays as well as their respective $\mathrm{LC}_{50}$ and $\mathrm{LC}_{90}$ confidence limits (CL). $\mathrm{LC}_{50}$ and $\mathrm{LC}_{90}$ values were estimated and significant differences were tested at the 0.05 level. Standard errors of the differences were estimated using the Delta method (Rao 1973).

\section{Results and Discussion}

Systemic Bioassays. Results from preliminary bioassays revealed no significant differences in response to insecticide treatments between the two chinch bug generations (data not shown). Therefore, bioassays were not conducted on both first and second generation chinch bugs. The lethal concentrations $\left(\mathrm{LC}_{50}\right.$ and $\mathrm{LC}_{90}$ ) for clothianidin, imidacloprid, and thiamethoxam were calculated for the tested chinch bugs and presented in Table 1 and 2 for nymphs and adults, respectively.

Comparing the lethal concentration $\left(\mathrm{LC}_{50}\right)$ values of imidacloprid and thiamethoxam to those reported for soybean aphid, Aphis glycines Matsumura, these insecticides were $\approx 1,000$-fold less toxic ( 31.3 and 16.9 $\mathrm{ng} / \mathrm{ml}$, respectively) to $B$. occiduus nymphs and adults (Magalhaes et al. 2008). However, for the A. glycines study mortality was evaluated after $7 \mathrm{~d}$ as opposed to $4 \mathrm{~h}$ in the current study. This longer insecticide exposure interval could explain the reduced toxicity to B. occiduus. Prabhaker et al. (2005) conducted a study on short-term exposure with neonicotinoid-susceptible sweetpotato whiteflies, Bemisia tabaci (Gennadius), and found that $48 \mathrm{~h}$ after treatment, inconsistencies existed between insecticide treatments. Imidacloprid and thiamethoxam $\mathrm{LC}_{50}$ values were 115 and $9.4 \mu \mathrm{g} / \mathrm{ml}$, respectively (Prabhaker et al. 2005). Comparing results between these two studies, $B$. occiduus adults seem to have similar levels of thiamethoxam susceptibility, whereas imidacloprid is less toxic to B. tabaci.

The tested insecticides adversely affected both chinch bug nymphs and adults maintained on treated buffalograss plants. However, there were no significant differences in toxicity for the nymphs among the toxicity of the three insecticides (Table 1). Despite the toxicity of clothianidin, imidacloprid, and thiamethoxam under controlled bioassay conditions, these same compounds failed to provide acceptable chinch bug control under field conditions (Anderson et al. 2005, Eickhoff et al. 2006). Although the established $\mathrm{LC}_{50}$ values do not correlate with the insecticide rates used for field applications, these bioassays suggest the lack of toxicity observed under field conditions may be due to unknown biotic and abiotic factors and plant responses and not related to inherent tolerance to neonicotinoid insecticides.

In adult bioassays, thiamethoxam was significantly more toxic than clothianidin or imidacloprid, with

Table 2. Adult B. occiduus susceptibility from exposure to clothianidin, imidacloprid, and thiamethoxam systemic bioassays

\begin{tabular}{lcccc}
\hline \hline Insecticide & $n$ & Slope $\pm \mathrm{SE}$ & $\mathrm{LC}_{50} \mu \mathrm{g} / \mathrm{ml}(95 \% \mathrm{CL})^{a}$ & $\mathrm{LC}_{90} \mu \mathrm{g} / \mathrm{ml}(95 \% \mathrm{CL})$ \\
\hline Thiamethoxam & 360 & $0.27 \pm 1.21$ & $5.75(3.35-8.15)$ & $13.83(8.85-18.81)$ \\
Clothianidin & 360 & $0.06 \pm 3.96$ & $16.39(8.54-24.23)$ & $50.87(26.32-75.42)$ \\
Imidacloprid & 360 & $0.05 \pm 4.30$ & $25.07(16.54-33.60)$ & $71.70(49.13-94.27)$ \\
\hline
\end{tabular}

${ }^{a}$ Concentration that produces $50 \%$ mortality in the population relative to the untreated controls. Calculated using a generalized linear model. 
Table 3. Nymphal B. occiduus susceptibility from exposure to bifenthrin, clothianidin, imidacloprid, and thiamethoxam contact bioassays

\begin{tabular}{lcccc}
\hline \hline Insecticide & $n$ & Slope $\pm \mathrm{SE}$ & $\mathrm{LC}_{50} \mu \mathrm{g} / \mathrm{ml}(95 \% \mathrm{CL})^{a}$ & $\mathrm{LC}$ 90 $\mu \mathrm{g} / \mathrm{ml}(95 \% \mathrm{CL})$ \\
\hline Bifenthrin & 360 & $127.52 \pm 0.001$ & $0.02(0.02-0.03)$ & $0.04(0.03-0.05)$ \\
Clothianidin & 350 & $1.35 \pm 0.18$ & $1.84(1.48-2.20)$ & $3.46(2.71-4.21)$ \\
Imidacloprid & 360 & $0.59 \pm 0.45$ & $2.55(1.65-3.44)$ & $6.27(4.07-8.47)$ \\
Thiamethoxam & 360 & $0.05 \pm 2.96$ & $40.57(34.72-46.42)$ & $89.18(75.34-103.02)$ \\
\hline
\end{tabular}

${ }^{a}$ Concentration that produces $50 \%$ mortality in the population relative to the untreated controls. Calculated using a generalized linear model.

thiamethoxam being approximately three-fold and five-fold more toxic to adult chinch bugs than either clothianidin or imidacloprid (Table 2). Interestingly, although clothianidin and imidacloprid were similarly toxic to both nymphs and adults, thiamethoxam was five-fold more toxic to chinch bugs adults.

Although clothianidin, imidacloprid, and thiamethoxam are in same insecticide class, differences in physical and chemical properties may influence their toxicity to B. occiduus. For example, thiamethoxam has greater water solubility $(4.1 \mathrm{~g} /$ liter $)$ than clothianidin (0.30-0.34 g/liter) and imidacloprid (0.61 g/liter) (Tomizawa and Casida 2005), suggesting thiamethoxam would be a more effective systemic insecticide. However, many biotic and abiotic environmental factors and plant responses are likely to affect toxicity under field conditions.

Contact Bioassays. Results from probit analysis for nymphs and adult contact bioassays are reported in Tables 3 and 4, respectively. All insecticides tested were toxic to both chinch bug nymphs and adults. As expected, bifenthrin was significantly more toxic than any of the neonicotinoids. Multiple insecticide efficacy trials conducted at the University of NebraskaLincoln have shown that bifenthrin is extremely toxic to B. occiduus (Wasem et al. 2007). Results from the contact bioassays support the results of these field efficacy trials. In nymphal bioassays, bifenthrin was $\approx 92-, 128$-, and 2,029-fold more toxic than clothianidin, imidacloprid, and thiamethoxam, respectively, and $\approx 122-$, 73-, and 39 -fold more toxic to adults. For the nymphal bioassays, there were no significant differences in $\mathrm{LC}_{50}$ values between clothianidin and imidacloprid. However, both insecticides were significantly more toxic $(\approx 20$-fold) to chinch bug nymphs than thiamethoxam (Table 3).

Significant differences were detected among the neonicotinoid insecticides in adult susceptibility. In contrast to the nymphal bioassays, thiamethoxam was more toxic than imidacloprid or clothianidin by approximately two-fold and three-fold, respectively (Table 4). As with the systemic bioassays discussed previously, thiamethoxam was more toxic to adults than to nymphs, whereas bifenthrin, clothianidin, and imidacloprid were more toxic to nymphs. Previous studies suggest neonicotinoid insecticides may have limited contact activity (Buchholz and Nauen 2001, Maienfisch et al. 2001), so this was not altogether unexpected. However, it remains unclear why thiamethoxam was more toxic to chinch bug adults than clothianidin or imidacloprid.

This is the first documented report of the doseresponse relationships for $B$. occiduus and the neonicotinoid insecticides. Adult and nymphal bioassays were designed to document the relative toxicities of these insecticides and provide estimates of chinch bug susceptibility through contact and ingestion after systemic uptake by the buffalograss. Results of these bioassays suggest that all three neonicotinoids tested are toxic to chinch bugs and also exhibit some contact activity.

Based on observed chinch bug mortality in the systemic bioassays, the neonicotinoid insecticides investigated seem to be translocated at lethal and sublethal concentrations up through the roots and into the stems and above ground leaf tissues where chinch bugs are feeding. It is well-documented that neonicotinoids are xylem-mobile compounds with translaminar movement in the leaves demonstrated an apoplastic translocation pathway, with systemic movement occurring via the xylem (Westwood et al. 1998, Buchholz and Nauen 2001, Maienfisch et al. 2001b, Weichel and Nauen, 2004). Anderson et al. (2006) showed that B. occiduus feeding on Prestige buffalograss frequently probed in the vascular tissue and bulliform cells. These tissues store water for the plant and may retain translocated insecticides. The tendency of the chinch bugs to probe in these locations could increase insecticide ingestion and mortality.

The contact bioassays suggested that all neonicotinoid insecticides tested have some contact activity against B. occiduus. Bifenthrin, however, was up to 1,844- and 122-fold more toxic to chinch bug nymphs and adults, respectively. This suggests that compared with the pyrethroids and insecticides with known con-

Table 4. Adult B. occiduus susceptibility from exposure to bifenthrin, clothianidin, imidacloprid, and thiamethoxam contact bioassays

\begin{tabular}{lcccc}
\hline \hline \multicolumn{1}{c}{ Insecticide } & $n$ & Slope $\pm \mathrm{SE}$ & $\mathrm{LC}_{50} \mu \mathrm{g} / \mathrm{ml}(95 \% \mathrm{CL})^{a}$ & $\mathrm{LC} 9 \mathrm{~g} / \mathrm{ml}(95 \% \mathrm{CL})$ \\
\hline Bifenthrin & 360 & $1.06 \pm 0.13$ & $0.37(0.12-0.63)$ & $14.35(8.17-20.54)$ \\
Thiamethoxam & 360 & $0.13 \pm 3.13$ & $27.14(18.47-35.82)$ & $31.84(16.83-46.85)$ \\
Imidacloprid & 360 & $0.04 \pm 4.39$ & $45.20(34.42-55.98)$ & $77.85(55.28-100.43)$ \\
Clothianidin & 350 & $0.03 \pm 5.45$ & $109.95(85.80-134.09)$ \\
\hline
\end{tabular}

${ }^{a}$ Concentration that produces $50 \%$ mortality in the population relative to the untreated controls. Calculated using a generalized linear model. 
tact toxicity, neonicotinoids may be relatively ineffective when topically applied. There were additional interesting anomalies among the neonicotinoids. The contact activity of thiamethoxam was $\approx 20$-fold less than clothianidin or imidacloprid to B. occiduus nymphs, but up to three-fold more toxic to adults. In adult systemic bioassays, thiamethoxam was up to fivefold more toxic than clothianidin or imidacloprid. Interestingly, thiamethoxam was the only compound more toxic to adults than to nymphs in both contact and systemic bioassays.

This study provides a better understanding of the toxicity of neonicotinoids insecticides to $\mathrm{B}$. occiduus and may have important implications for B. occiduus management. Traditionally, recommendations have suggested that insecticide applications should be timed to control chinch bugs while they are still in their early developmental stages (Baxendale and Gaussoin 1997). However, results from the systemic bioassays suggest no differences in susceptibility among age classes to either clothianidin or imidacloprid. With these insecticides, treating smaller nymphs seem to be less important than proper application techniques and administering the correct rate of insecticide targeting active chinch bugs infestations.

\section{Acknowledgments}

We acknowledge Leonardo Magalhaes and Haichuan "John" Wang for assistance in a development of bioassay methods. We also thank Nicholas Aliano and Timothy Husen for technical help and support.

\section{References Cited}

Anderson, W. G., T. E. Eickhoff, and T. M. Heng-Moss. 2005. Evaluation of Arena for control of first generation chinch bugs, 2004. Arthropod Manag. Tests 30.

Anderson, W. G., T. M. Heng-Moss, F. P. Baxendale, L. M. Baird, G. Sarath, and L. G. Higley. 2006. Chinch Bug (Hemiptera: Blissidae) mouthpart morphology, probing frequencies, and locations on resistant and susceptible germplasm. J. Econ. Entomol. 99: 212-221.

Badio, B., and J. W. Daly. 1994. Epibatidine, a potent analgesic and nicotinic agonist. Mol. Pharmacol. 45: 563-569.

Baxendale, F. P., and R. E. Gaussoin. 1997. Integrated Turfgrass management for the Northern Great Plains. EC971557. University of Nebraska Extension, Lincoln, NE.

Baxendale, F. P., T. M. Heng-Moss, and T. P. Riordan. 1999. Blissus occiduus (Hemiptera: Lygaeidae): a chinch bug pest new to buffalograss turf. J. Econ. Entomol. 92: 11721176.

Bird, R. D., and A. V. Mitchener. 1950. Insects of the season 1949 in Manitoba. Can. Insect Pest Rev. 28: 41.

Buchholz, A., and R. Nauen. 2001. Translocation and translaminar bioavailability of two neonicotinoid insecticides after foliar application to cabbage and cotton. Pest Manag. Sci. 58: 10-16.

Eickhoff, T. E., R. W. Baxendale, L. Toda, and F. P. Baxendale. 2006. Residual control of chinch bugs with Allectus insecticide, 2005. Arthropod Manag. Tests 31.

Eickhoff, T. E., T. M. Heng-Moss, F. P. Baxendale, and J. E. Foster. 2008. Levels of tolerance, antibiosis, and antixenosis among resistant buffalograsses and zoysiagrasses. J. Econ. Entomol. 101: 533-540.
Elbert, A., M. Haas, B. Springer, W. Thielert, and R. Nauen. 2008. Applied aspects of neonicotinoid uses in crop protection. Pest Manag. Sci. 64: 1099-1105.

Elliot, M., N. F. Janes, and C. Potter. 1978. The future of pyrethroids in insect control. Annu. Rev. Entomol. 23: 443-469.

Finney, D. J. 1971. Probit analysis, 3rd ed. Cambridge University Press, Cambridge, England.

Heng-Moss, T. M., F. P. Baxendale, T. P. Riordan, and J. E. Foster. 2002. Evaluation of buffalograss germplasm for resistance to Blissus occiduus (Hemiptera: Lygaeidae). J. Econ. Entomol. 95: 1054-1058.

Heng-Moss, T. M., F. P. Baxendale, R. C. Shearman, and T. E. Eickhoff. 2005. Resistant turfgrasses for improved chinch bug management. USGA Turfgrass and Environmental Research Online. 4: 1-7. (http://usgatero.msu. edu/currentpastissues.htm\#2005).

Magalhaes, L. C., T. E. Hunt, and B. D. Siegfried. 2008. Development of methods to evaluate susceptibility of soybean aphid to imidacloprid and thiamethoxam at lethal and sublethal concentrations. Entomol. Exp. Appl. 128: $330-336$.

Maienfisch, P., H. Huerlimann, A. Rindlisbacher, L. Gsell, H. Dettwiler, J. Haettenschwiler, E. Sieger, and M. Walti. 2001a. The discovery of thiamethoxam: a second-generation neonicotinoid. Pest Manag. Sci. 57: 165-176.

Maienfisch, P., M. Angst, F. Brandl, W. Fischer, D. Hofer, H. Kayser, W. Kobel, A. Rindlisbacher, R. Senn, A. Steinemann, et al. 2001b. Chemistry and biology of thiamethoxam: a second generation neonicotinoid. Pest Manag. Sci. 57: 906-913.

Nauen, R., and A. Elbert. 1994. Effect of imidacloprid on aphids after seed treatment of cotton in laboratory and greenhouse experiments. Pflanzenschutz-Nachr Bayer. 47: 181-216.

Nauen, R., H. Hungenberg, B. Tollo, K. Tietjen, and A. Elbert. 1998. Antifeedant effect, biological efficacy and high affinity binding of imidacloprid to acetylcholine receptors in Myzus persicae and Myzus nicotianae. Pestic. Sci. 53: 133-140.

Painter, R. H. 1928. Notes on the injury to plant cells by chinch bug feeding. Ann. Entomol. Soc. Am. 21: 232-242.

Prabhaker, N., S. Castle, T. J. Henneberry, and N. C. Toscano. 2005. Assessment of cross-resistance potential to neonicotinoid insecticides in Bemisia tabaci (Hemiptera: Aleyrodidae). Bull. Entomol. Res. 95: 535-543.

Potter, D. A. 1998. Destructive turfgrass insects: biology, diagnosis, and control. Ann Arbor Press, Cheslea, MI.

Rao, C. R. 1973. Linear statistical inference and its applications, 2nd ed. Wiley, New York.

Slater, J. A. 1964. A catalogue of the Lygaeidae of the world, vol. 2. University of Connecticut, Storrs, CT.

SAS Institute 2006. SAS/STAT user's guide, version 9.1. SAS Institute, Cary, NC.

Scharf, M. E., L. J. Meinke, B. D. Siegfried, R. J. Wright, and L. D. Chandler. 1999. Carbaryl susceptibility, diagnostic concentration determination and synergism for U.S. populations of western corn rootworm. J. Econ. Entomol. 92: 33-39.

Soloway, S. B., A. C. Henry, W. D. Kollmeyer, W. M. Padgett, J. E. Powell, S. A. Roman, C. H. Tieman, R. A. Corey, and C. A. Horne. 1978. Nitromethylene heterocycles as insecticides, pp. 153-158. In D. L. Shankland, R. M. Hollingworth, and T. Smyth (eds.), Pesticide and venom neurotoxicity. Plenum, New York.

Tomizawa, M., and J. E. Casida. 2005. Neonicotinoid insecticide toxicology: mechanisms of selective action. Annu. Rev. Pharmacol. 45: 247-268. 
Wasem, C. M., M. D. Stamm, and T. M. Heng-Moss. 2007. Residual control of chinch bugs with selected pyrethroids on fertilizer carriers, 2006. Arthropod Manag. Tests 32 .

Weichel, L., and R. Nauen. 2004. Uptake, translocation and bioavailability of imidacloprid in several hop varieties. Pest Manag. Sci. 60: 440-446.
Westwood, F., K. M. Bean, A. M. Dewar, R. H. Bromilow, and K. Chamberlain. 1998. Movement and persistence of $\left[{ }^{14} \mathrm{C}\right]$-imidacloprid in sugar-beet plants following application to pelleted sugar-beet seed. Pestic. Sci. 52: 97-103.

Received 16 July 2010; accepted 18 October 2010 